Original Article

\title{
HONEY BEE INFECTION CAUSED BY NOSEMA SPP. IN LITHUANIA
}

\author{
Laima Blažytè-Čereškienè* \\ Vesta Skrodenytè-Arbačiauskienè \\ Sandra Radžiutè \\ Irena Nedveckytè \\ Vincas Būda \\ Nature Research Centre, Akademijos 2, LT-08412 Vilnius, Lithuania \\ * corresponding author: blazyte@ekoi.lt \\ Received: 18 January 2016; accepted: 26 October 2016
}

Abstract

\begin{abstract}
The infection of Lithuanian honey bee colonies by Nosema apis and $N$. ceranae and the consequences were analysed over a four-year (2011 - 2014) period. Both mono-infection either by $\boldsymbol{N}$. apis or $\boldsymbol{N}$. ceranae, and co-infection by both Nosema species, were found. There was a decrease in the percentage of Nosema infected colonies during the four-year study period. There were fewer colonies infected by $\boldsymbol{N}$. ceranae, whereas the number of colonies with $\boldsymbol{N}$. apis remained approximately at the same level during the study. The prevalence of both types of Nosema in honey bee colonies varied seasonally, i.e. there was a higher percentage of colonies infected in spring and summer but very rarely was Nosema detected in autumn. Mono-infection by $\mathrm{N}$. apis, and co-infection by both Nosema species, were significantly more often recorded in weak and moderate colonies than in strong colonies. Mono-infection by $\mathbf{N}$. ceranae was more often detected in weak colonies than in moderate and strong colonies, but more often detected in strong than in moderate colonies. A moderate link between a high prevalence of $\boldsymbol{N}$. ceranae infection and an increased risk for winter colony mortality was observed.
\end{abstract}

Keywords: colony losses, Nosema apis, Nosema ceranae, Apis mellifera, seasonality

\section{INTRODUCTION}

Nosemosis is a disease of honey bees caused by two species of microsporidia; Nosema apis (Zander, 1909) and N. ceranae(Fries et al., 1996). For a time, it was assumed that $N$. apis was a pathogen specific to the European honey bee, Apis mellifera(Ellis \& Munn, 2005), and N. ceranae specific to the Asian honey bee, A. cerana (Fries et al., 1996). However, many recent reports have revealed that $N$. ceranae has successfully infected $A$. mellifera worldwide (Higes, Martín, \& Meana, 2006; Klee et al., 2007; Martín-Hernández et al., 2007; Paxton et al., 2007; Chen et al., 2008; Invernizzi et al., 2009; Tapaszty et al., 2009; Stevanovic et al., 2013; BlažytèČereškienè, Skrodenytè-Arbačiauskienè, \& Būda, 2014). Nosema ceranae was considered an emergent pathogen suspected to replace $N$. apis in A. mellifera (Klee et al., 2007). There is increasing evidence that the pathogen has been present in the European honey bee for longer than 20 years (Paxton et al., 2007; Chen et al., 2008; Invernizzi et al., 2009). During the last 10 years, nosemosis in European honey bees caused by $N$. ceranae has been considerably more prevalent than that caused by $N$. apis in warmer climates (Tapaszty et al., 2009; Stevanovic et al., 2011), whereas $N$. apis remains more prevalent in colder climate regions (Budge et al., 2010; Gisder et al., 2010). There was a difference in the prevalence of N.ceranae in Scandinavian countries. In Finland, N. ceranae is more prevalent compared to Sweden and Norway although the climate conditions are similar (Klee et al., 2007; Paxton et al., 2007). Little is known of the current situation of nosemosis caused by $N$. ceranae in the Baltic countries. During the 2012 - 2013 time period, the clinical prevalence of nosemosis was not observed in Latvia and, though the species of Nosema was not identified, it barely exceeded $3.1 \%$ in Estonian honey bee colonies (Chauzat et al., 2014). In Lithuania, N. ceranae was detected in 2011, with a pronounced prevalence (up to $59 \%$ in the south and west part of the country, 
while $N$. apis prevailed (up to 50\%) in the rest of the country (Blažytè-Čereškienè, SkrodenytèArbačiauskienè, \& Būda, 2014).

Currently, the nosemosis caused by these two microsporidia species occurs in honey bee colonies worldwide and has been shown to have a number of negative impacts on honey bee colonies, depending on the geographic location and the Nosema species involved. Damage may cause a shortened worker lifespan (Fries, Ekbohm, \& Villumstad, 1984; Higes et al., 2007), reduced colony productivity (Anderson \& Giacon, 1992), and altered pheromone production by honey bee workers and queens that could induce queen supersedure (Dussaubat et al., 2010; Alaux et al., 2011). Reports on the impact of Nosema infection on colony survival are contradictory. Thus, Nosema infection's role in colony losses is not fully understood (Paxton, 2010). In Spain, heavy colony losses have been attributed to $N$. ceranae infection (Higes et al., 2008). Studies in some other European countries (Poland, Austria, and France) have suggested that $N$. ceranae infection could be related to the mortality of honey bee colonies (Derakhshifar et al., 2009; Gajda \&Topolska, 2009; Chauzat et al., 2010). Several investigations from different geographical regions were made. It was found that though colony losses did not correlate with $N$. apis or $N$. ceranae infection, the infection combined with other synergistic factors might be involved in colony losses (Cox-Foster et al., 2007; Topolska, Gajda, \& Hartwig, 2008; Ratnieks \& Carreck, 2010). Among such factors, differences in climatic conditions in geographical regions may be important. In most areas, the $N$.apis infection level typically peaks in spring and decreases during summer and autumn (Pickard \& El-Shemy, 1989; Martín-Hernández et al., 2007; Gisder et al., 2010; Mariani et al., 2012), whereas seasonal variation of $N$. ceranae infection depends on geographical region. Martín-Hernández et al. (2007) reported that no seasonal differences were found in the prevalence of $N$. ceranae in honey bee samples during 2005 year in Spain. However, Traver, Williams, \& Fell (2012) found seasonal variation in $N$. ceranae infection over a 13-month sampling period in the USA. There was a similar seasonal variation in infection observed in Germany (Gisder et al., 2010) and Canada (Copley \& Jabaji, 2012). Insufficient data on the impact of Nosema infection (especially that caused by $N$. ceranae) on $A$. mellifera in different areas in Europe, suggest a need for such an investigation in different geographical areas and climatic conditions (Fries, 2010). The Baltic countries, including Lithuania, аге in the temperate continental climate zone with pronounced seasonality i.e. warm, dry summers and fairly severe winters. Thus, in our four-year (2011 - 2014) investigation, we studied the prevalence of Nosema infection in honey bee colonies in Lithuania. We tried to define if $N$. ceranae and $N$. apis infections in honey bee colonies varied seasonally, how the infections were related to colony strength, and if the infections were related to winter colony losses.

\section{MATERIAL AND METHODS}

\section{Honey bee samples}

In the present study, the prevalence of two microsporidia species, i.e. $N$. apis and $N$. ceranae, in Lithuanian apiaries, was investigated. Live worker honey bees (Apis mellifera L.) were collected at 44 apiaries from 130 colonies in 2011 (April - July), at 36 apiaries from 174 colonies in 2012 (July - October), at 30 apiaries from 129 colonies in 2013 (June - July), and at 22 apiaries from 110 colonies in 2014 (May September) (Tab. 1). For sampling, two to six colonies per apiary were selected randomly, irrespective of signs of any disease. Yearly sampling was performed in the same apiaries and in the same colonies. However, the number of tested apiaries decreased as some beekeepers refused to participate during the course of the survey. Moreover, many beekeepers were moving their colonies from one apiary to other. This meant that during the four-year study, just 15 colonies were sampled four times, 29 colonies were sampled three times, 94 colonies twice, and 209 colonies were sampled once. In total, 347 honey bee colonies were tested.

Bees were collected at the hive entrance or 
Table 1

Number of honey bee colonies sampled in the three seasons during the four-year study period (2011 - 2014)

\begin{tabular}{ccccc}
\hline & \multicolumn{4}{c}{ Year } \\
\cline { 2 - 5 } & 2011 & 2012 & 2013 & 2014 \\
\hline Spring (April - May) & 67 & - & - & 29 \\
Summer (June - July) & 63 & 40 & 129 & 44 \\
Autumn (September - October) & - & 134 & - & 37 \\
Total number of colonies tested & 130 & 174 & 129 & 110 \\
\hline
\end{tabular}

on frames away from the brood nest following the OIE guidelines (OIE, 2008). Each sample contained bees from a single colony only. Bee samples were frozen and stored at $-20^{\circ} \mathrm{C}$ until used for suspension preparation.

\section{Colony strength estimation}

Each of the beekeepers was asked to answer some questions about the strength of the colonies sampled and the survival of the colonies in the apiary during the winters of the study (2010/2011, 2011/2012, 2012/2013, and 2013/2014). Beekeepers rated the strength of their colonies as weak, moderate or strong according to the number of frames of broods in each colony, the signs of nosemosis and the amount of honey production. The information on 335 colonies sampled for Nosema detection during summer over the four-year study period was obtained.

\section{DNA extraction and identification of Nosema species}

Abdomens of ten adult bees from each colony (according Martín-Hernández et al., 2007) were homogenised in a mortar with $4 \mathrm{~mL}$ of deionised water. For DNA extraction, $1 \mathrm{~mL}$ of spore suspension was centrifuged (5 min, $16100 \mathrm{~g}$ ) and supernatant discarded. Pellets were frozen in liquid nitrogen and crushed using sterile pellet pestles. DNA was extracted with the use of a DNeasy Plant Mini Extraction Kit (Qiagen). The extracts were stored at $-20^{\circ} \mathrm{C}$ until PCR.

For Nosema detection and determination of Nosema species, a duplex-PCR with species-spe- cific primers (321APIS-FOR/REV for detection of N. apis and 218 MIROC-FOR/REV for detection of $N$. ceranae) was used (Martin-Hernandez et al., 2007). The PCR mixtures contained DreamTaq ${ }^{T M}$ Green PCR Master Mix (Thermo Scientific) $25 \mu \mathrm{L}$, $0.4 \mu \mathrm{M}$ of each species-specific primer (FOR/ REV), $1 \mu$ of template DNA and water nucleasefree (Thermo Scientific) in a total volume of 50 $\mu \mathrm{L}$. Amplifications were performed in Mastercycler $^{\oplus}$ nexus (Eppendorf) thermal cycler using a cycling program as previously described in detail (Stevanovic et al., 2011). The PCR products were electrophoresed in $1 \%$ agarose gel (1xTBE, Thermo Scientific) containing $1 \mathrm{ng} / \mathrm{mL}$ Midori Green (NIPPON Genetics EUROPE), and visualised under UV light. Fragment sizes were determined with reference to GeneRuler ${ }^{T M}$ Low Range DNA Ladder (Thermo Scientific).

The PCR products were extracted from the agarose gel using a GeneJET Gel Extraction kit (Thermo Scientific). The PCR fragments were sequenced by automated DNA sequencing. The 16S rRNA gene sequences of $N$. apis and $N$. ceranae were similar to sequences from Lithuania deposited in the DDBJ/EMBL/ GenBank databases earlier (Blažytè-Čereškienè, Skrodenytè-Arbačiauskienè, \& Būda, 2014).

\section{Statistical analysis}

The analysis was performed using Statistic 6.0 software package (StatSoft, Inc., Tulsa, OK, USA). The chi-square test was used to compare the proportion of Nosema-positive colonies among weak, moderate, and strong colonies. The Kruskal-Wallis test was used to compare colony 
$\square$ Only N. apis \% $\quad \square$ Only N. ceranae \% $\quad \square$ Co-infect \% $\square$ No Nosema \%

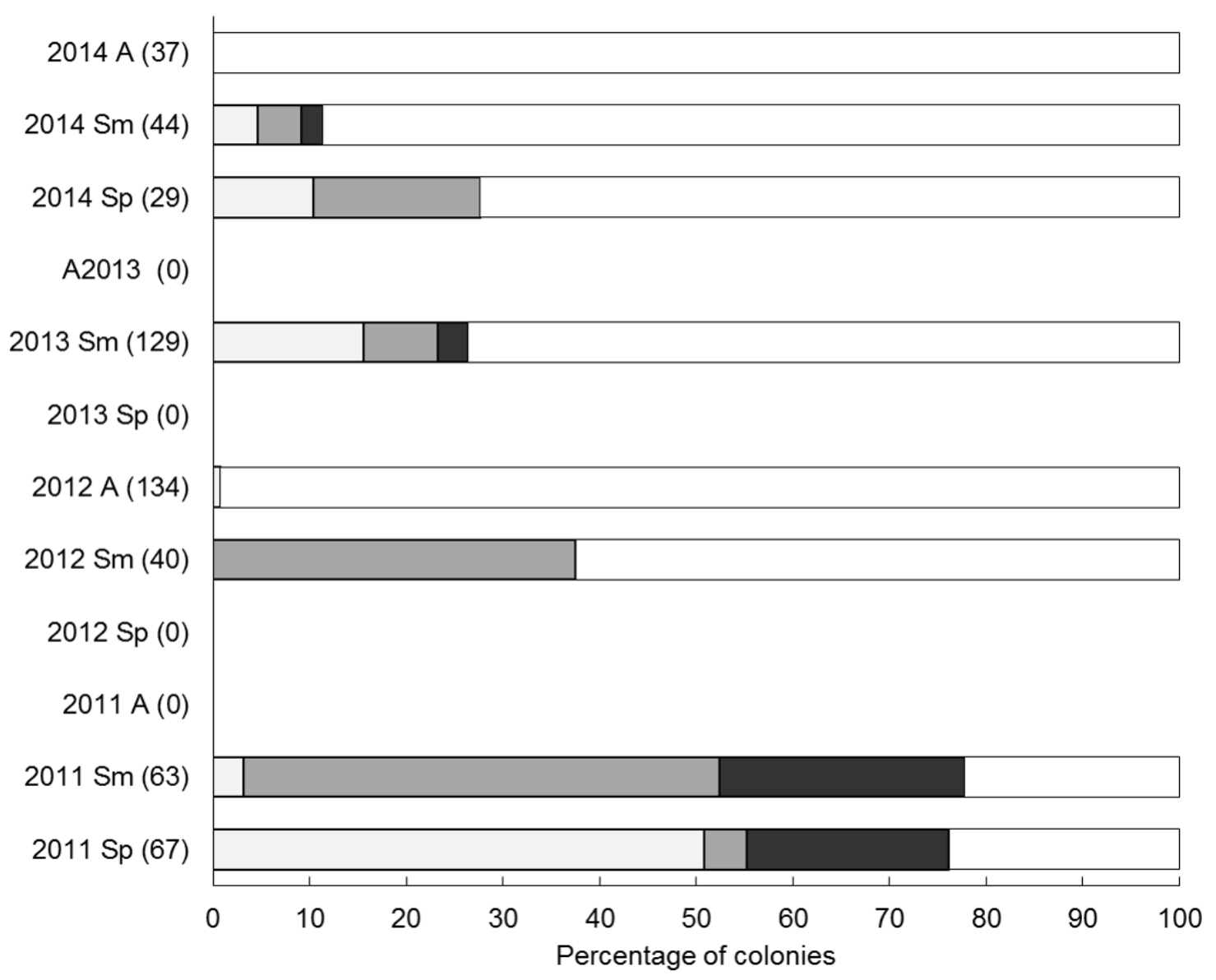

Fig.1

Prevalence of Nosema apis and N. ceranae in honey bee colonies during the four-year (2011 - 2014) study period in Lithuania.

losses in different years. The Spearman rank order correlation analysis was used to estimate the relationship between Nosema infection and colony losses in the following winter season. $A$ p-value of $<0.05$ was considered significant.

\section{RESULTS}

\section{Prevalence of Nosema spp.}

A total of 347 honey bee colonies were tested for the presence of Nosema infection over a four-year (2011 - 2014) period. Nosema was detected in 153 colonies (44\%) at least once throughout the study. Mono-infection by $N$. apis or $N$. ceranae, and co-infection by $N$. apis and N.ceranae, were detected. Infection by $N$. ceranae was detected in $27.7 \%$ of colonies and by $N$.apis in $27.1 \%$ of colonies, i.e. infection by each parasite species was at a very similar level. Among infected colonies, $38.6 \%$ contained
N. ceranae only, and $37.2 \%$ contained $N$. apis only, while $24.2 \%$ of the colonies were infected by both Nosema species.

In colonies which were tested at least twice during the four-year period, the recurrence of the Nosema infection was detected in five of them (3.27\%): $N$. apis was detected twice in three colonies (1.96\%), $N$. ceranae was detected twice in a single colony $(0.65 \%)$, and in a single colony $(0.65 \%) N$. cerane (present for two consecutive years) was replaced by $N$. apis (in the third year).

The most Nosema-positive colonies were detected in spring and summer of 2011: 76.1\% and $77.8 \%$, respectively. In 2014, infection was found in $27.6 \%$ of the colonies in spring and in $11.4 \%$ of the colonies in summer. In honey bee samples collected in autumn, Nosema was detected only in a single colony (from 134) in 2012. Analysing N. apis and N. ceranae as a single 


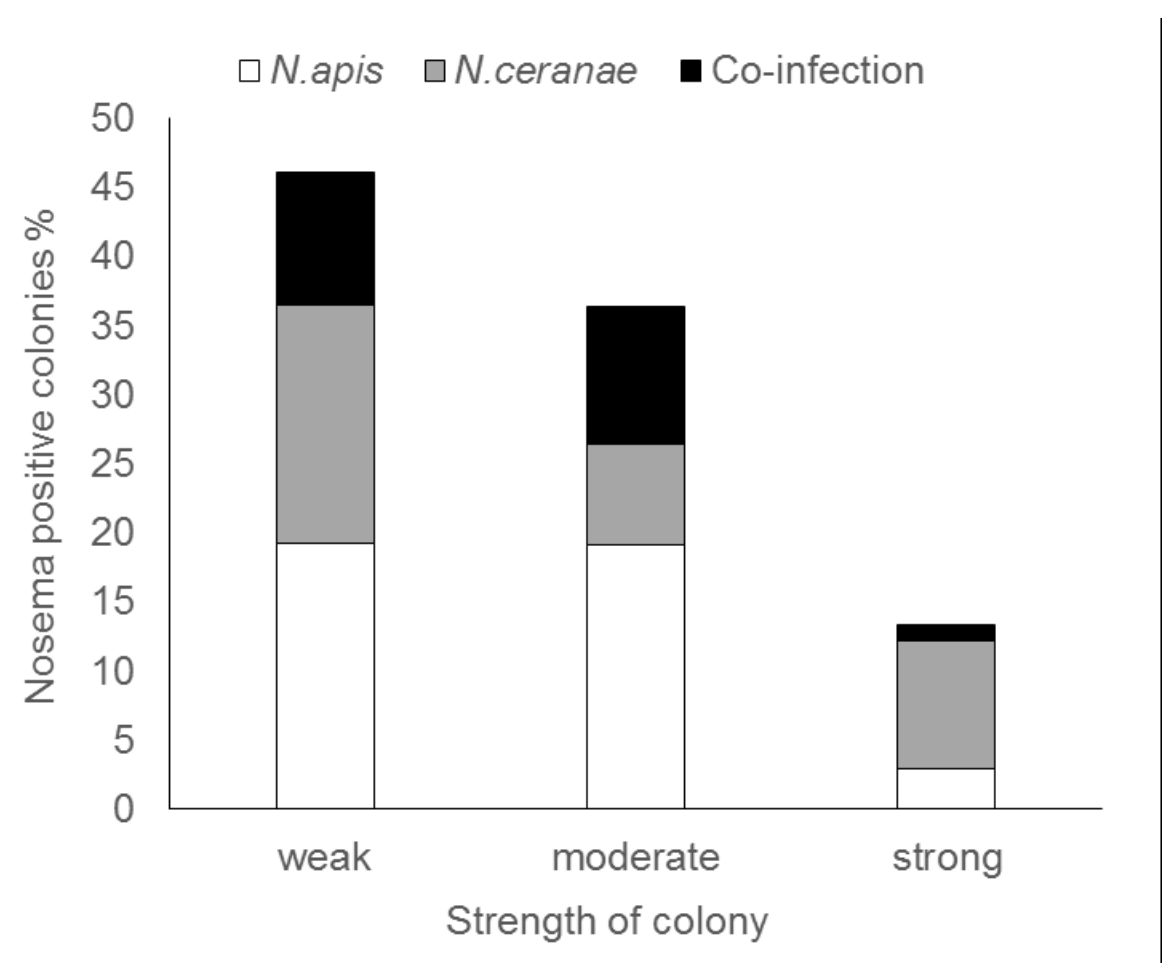

Fig.2

Relationship between the colony strength (weak, moderate, and strong) and the type of Nosema spp. infection (mono-infection by either N. apis or N. ceranae, and co-infection by both $N$. apis and N. ceranae). The results are based on the summer samples only.

infection, $N$. apis was found to be more prevalent in spring, whereas $N$. ceranae was most common in spring and summer. Co-infection by both $N$. ceranae and $N$. apis was most common in summer. Thus, the results of the 4-year study suggested that Nosema infection in honey bee colonies varied depending on the season.

Based on an analysis of summer samples only, most Nosema-positive colonies were detected in 2011 (78\%), while infection was found in 11\% of the colonies in 2014. In summer, the level of infection by $N$. apis was approximately the same during the 2011 - 2014 period and did not exceed $15 \%$ of the colonies. While the infection level by $N$. ceranae decreased during the same period from $49 \%$ of the colonies in 2011 to $4.5 \%$ of the colonies in 2014 (Fig. 1). Co-infection by $N$. ceranae and $N$. apis varied during this period: the highest level of co-infection was detected in 2011 (25\%), and the lowest in 2013 and 2014 (approximately 2 - 3\% of the colonies). So, the number of $N$. ceranae infected colonies decreased from 2011 to 2014.

\section{Infection and colony strength}

Beekeepers rated the strength of their colonies as weak, moderate or strong. The main signs of colony weakness as noted by the beekeepers: were a low number of worker bees and the slow development of a colony (37\% of colonies), low honey production (23\%), sick brood (14\%), faecal marks and sick adult bees (21\%), and queen loss (5\%). Based on such data, $52 \%$ of the colonies were defined as strong, 33\% as moderate, and $15 \%$ as weak. With the aim of determining whether colony strength was related to Nosema infection and whether colonies rated as weak by beekeepers had significantly higher levels of Nosema, statistical analysis was applied. The chi-square test revealed that Nosema was significantly more present in weak (46\%) and moderate $(36 \%)$ colonies than in strong $(13 \%)$ colonies (weak vs. strong: $\chi^{2}=26.1, \mathrm{P}<0.01$; moderate vs. strong: $\chi^{2}=20.7, \mathrm{P}<0.01$ ). The difference was found both for mono-infection by $N$. apis and for co-infection by both Nosema species. Whereas mono-infection by $N$. ceranae was more present in weak colonies than in moderate and strong ones (weak vs. strong: $\chi^{2}=4.9, \mathrm{P}=0.03$; weak vs. moderate: $\chi^{2}=8.0$, $\mathrm{P}<0.01$; moderate), and more present in strong colonies compare to moderate ones $\left(\chi^{2}=15.2\right.$, $\mathrm{P}<0.01$ ) (Fig. 2). 


\section{Infection and colony losses}

In order to evaluate the impact of Nosema infection on the mortality of honey bee colonies, we related the overwintering losses to the detection of the two Nosema species; $N$. apis, and $N$. ceranae. Based on the beekeepers' information, colony losses varied from $2.8 \%$ to $13.1 \%$ during the 2011 - 2014 period. No statistically significant differences were revealed in colony losses during the study among the sampled apiaries $(H=5.1, d f=3, P>0.05)$. No statistically significant correlation was found between $N$. apisinfection and colony losses in the following season ( $P>0.05)$. However, correlation analysis revealed a moderate relationship between $N$. ceranae infection in 2011 and colony losses in the following winter $(2011 / 2012)\left(r_{s}=0.58\right.$, $\mathrm{t}=2.5, \mathrm{P}=0.03$ ).

\section{DISCUSSION}

Our four-year study revealed that honey bee colonies in Lithuania were infected by both Nosema species. Mono-infections either by $N$. apis or $N$. ceranae, and co-infection by both Nosema species were found. The total prevalence of infection during the whole study period was approximately $44 \%$, and infection by each Nosema sp. was at a very similar level. The number of infected colonies might be higher as Nosema-free colonies could still bear microsporidia that were undetected since the tested samples only contained ten bees, and this could cause an underestimation of the pathogens' presence. If the estimated prevalence of Nosema-species-infection was compared between years, however, we found that the number of infected colonies decreased. The decrease in the level of Nosema infection was due to the decrease in the number of colonies infected by $N$. ceranae, whereas the number of colonies with $N$. apis remained approximately at the same level during the study period. Thus, the study did not confirm our assumption that invasive N.ceranae was replacing the local parasite $N$.apis in Lithuanian honey bee colonies (Blažytè-Čereškienè, Skrodenytè-
Arbačiauskienè, \& Būda, 2014). However, the replacement of $N$. apis by $N$. ceranae seems to have occurred in different regions of Europe and in the US (Botias et al., 2012; Chen et al., 2008). Nosema ceranae has become more prevalent than Nosema apis in Spain, Denmark, Italy, Poland, Greece, and the Balkan countries (Klee et al., 2007; Tlak Gajger et al., 2010; Michalczyk et al., 2011, 2013; Stevanovic et al., 2011; Botias et al., 2012). Nosema apis remains prevalent in Sweden and the United Kingdom (Klee et al., 2007). In Lithuania, infection by each parasıte species was at a very similar ievei, and this situation corresponds to that reported in Germany (Gisder et al., 2010).

Although there were analysed samples collected in 4 summer seasons and those collected in 2 spring and autumn seasons, the main trend became clear: in spring and summer honey bee colonies were infected by both $N$. apis and $N$. ceranae, while in autumn the microsporidia infection level decreased (Nosema apis was detected in a single colony only). Our results indicated that the prevalence of Nosema in Lithuanian honey bee colonies varied seasonally. In Lithuania, the observed seasonal prevalence of $N$. apis infection was in agreement with that previously reported as characteristic to a temperate climate zone: i.e. a peak in spring and low prevalence during summer and autumn (Fries, 2010; Gisder et al., 2010). The seasonal prevalence of $N$. ceranae infection in Lithuanian honey bee colonies was quite similar to the seasonality observed in the north-eastern part of Germany where the proportion of colonies with $N$. ceranae was always higher in spring than in autumn (Gisder et al., 2010). However, it was different from that reported by Martín-Hernández et al. (2007) in Spain, and by Stevanovic et al. (2013) in Serbia. In Spain, Martín-Hernández et al. (2007) observed a total lack of seasonality of $N$. ceranae infection. In Serbia, the highest prevalence of $N$. ceranae was recorded in spring, with a lower prevalence in summer and then an increase in autumn, but the proportion of infected colonies was always high (never below 73\%) (Stevanovic et al., 2013). Hence, our study confirms that the pronounced seasonal variation 
of $N$. ceranae prevalence is characteristic of countries with cool climate conditions.

The diagnosis of Nosema-infected colonies in the field is possible if the honey bees are infected by $N$. apis (such as dysentery accompanied by defecation within the hive and crawling bees). However, the diagnosis of colonies infected by $N$. ceranae is almost impossible due to a lack of infection signs (Fries, 2010). In Serbia, though, the symptoms traditionally attributed to $N$. apis infection were also observed in colonies infected by $N$. ceranae (Stevanovic et al., 2013). In Lithuania, our study revealed that the colonies rated by beekeepers as weak and moderate were more often infected by $N$. apis than strong colonies were. The symptoms of nosemosis (faecal marks and sick adult bees) were noted in $21 \%$ of weak colonies. A low number of worker bees and a slow increase in numbers were the main indicators of colony weakness most frequently denoted by beekeepers. Among strong colonies infected by Nosema, most contained mono-infection by N.ceranae. We assume the reason for that might be recent infection and a still low negative impact. Besides, such colonies were detected in apiaries maintained by professional beekeepers, who take special measures to prevent colony weakening, i.e. merge colonies, change queens etc.

Infections by $N$. ceranae have been suggested to be implicated in severe colony losses in Spain (Higes et al., 2008, 2009). Similar colony losses that could be attributed to $N$. ceranae have been reported in Poland, Finland, Denmark, and Turkey (Gajda \& Topolska, 2009; Korpela, 2009; Vejsnæs, Nielsen, \& Kryger, 2010; Whitaker, Szalanski, \& Kence, 2011). However, in other countries (Germany, France, Serbia, the USA, etc.) no relationship between infection by Nosema species and winter losses have been revealed (Chauzat et al., 2007; van Engelsdorp et al., 2009; Genersch et al., 2010; Dainat et al., 2012; Stevanovic et al., 2013). Likewise, the results obtained in our study did not reveal a relation between $N$. apis as mono-infection and losses the following winter. Though the cause of colony losses cannot be conclusively attributed to $N$. ceranae infection, we found a significant but moderate correlation between the presence of the infection in 2011 and the occurrence of losses in the following winter (2011/2012). During the winter of 2011/2012, colony losses amounted to about $10 \%$ only, but most of the colonies that did not survive the winter were in apiaries infected by $N$. ceranae. In 2011, N. ceranae was widespread in Lithuanian apiaries, possibly due to climatic changes in the country. Based on the data reported by the Lithuanian Hydrometeorological Service for the past decade, the average temperatures were continually increasing: in the first half of 2011, the average temperature was $3^{\circ} \mathrm{C}$ higher than the temperature averages of previous years (Aplinkos būklè 2011. Tik faktai, 2012). Possibly, there were congenial conditions for the spread of southern-origin parasites, and $N$. ceranae might have been transferred to autumn bees. Insufficient food stores were the usual cause of honey bee death indicted by beekeepers. Knowing the role of $N$. ceranae in honey bee immune suppression (Antúnez et al., 2009; Chaimanee et al., 2012) and induced energetic stress (Mayack \& Naug, 2009), we assume that this parasite could be one of the causative factors of colony mortality during the winter of 2011/2012.

In summary, during the four-year period, the percentage of $N$. ceranae-infected colonies decreased. In honey bee colonies in Lithuania, $N$. ceranae has not replaced $N$. apis. Such a situation is likely to be observed in other Baltic countries and in regions with similar climatic conditions. The prevalence of both types of nosemosis in honey bee colonies varied seasonally. A moderate link between a high prevalence of $N$. ceranae infection and an increased risk of colony mortality was established.

\section{ACKNOWLEDGEMENTS}

We thank the many beekeepers for their kindly permitting us to collect bee samples in their apiaries. We also thank Ms. Virginija Žalienè and Mr. Jos Stratford for their English text correction. This study was funded by a grant (Contract No LEK-01/2012) from the Research Council of 
Lithuania. Open Access to the research infrastructure of the Nature Research Centre under the Lithuanian open access network initiative, is acknowledged.

\section{REFERENCES}

Alaux, C., Folschweiller, M., McDonnell, C., Beslay, D., Cousin, M., Dussaubat, C., Brunet, J.L., Le Conte, Y. (2011). Pathological effects of the microsporidium Nosema ceranae on honey bee queen physiology (Apis mellifera). Journal of Invertebrate Pathology, 106, 380-385. DOl: 10.1016/j.jip.2010.12.005

Anderson, D.L., \& Giacon, H. (1992). Reduced pollen collection by honeybee (Hymenoptera, Apidae) colonies infected with Nosema apis and sacbrood virus. Journal of Economic Entomology, 85, 47-51. DOl: 10.1093/jee/85.1.47

Antúnez, K., Martín-Hernández, R., Prieto, L., Meana, A., Zunino, P., Higes. M. (2009). Immune suppression in the honey bee (Apis mellifera) following infection by Nosema ceranae (Microsporidia). Environmental Microbiology, 17, 2284-2290. DOl: 10.1111/j.14622920.2009.01953.x

Aplinkos büklé 2017. Tik faktai (2012). [Environment State in 2011. The facts]. Aplinkos apsaugos agentūra, Vši Gamtos paveldo fondas, Vilnius.

Blažytè-Čereškienè, L., Skrodenytè-Arbačiauskienè, V., \& Būda. V. (2014). Microsporidian parasites of honey bees Nosema ceranae and $N$. apis in Lithuania: supplementary data on occurrence along Europe. Journal of Apicultural Research, 53(3), 374376. DOl: 10.3896/IBRA.1.53.3.04

Botías, C., Martín-Hernández, R., Garrido-Bailón, E., González-Porto, A., Martínez-Salvador, A., Pilar De La Rúa, Meana, A., Higes, M. (2012). The growing prevalence of Nosema ceranae in honey bees in Spain, an emerging problem for the last decade. Research in Veterinary Science, 93, 150-155. DOl: 10.1016/j. rvsc.2011.08.002

Budge, G., Powell, M., Roberts, K., Adams, I., Jones, B., Marris, G., Laurenson, L., Wilkins, S., Pietravalle, S.,
Brown, M. (2010). What has Nosema got to do with losses? Monitoring both Nosema species in the UK. In Proceedings of the 4th European Conference of Apidology (p. 48). Ankara - Turkey.

Chaimanee, V., Chantawannakul, P., Chen, Y., Evans, J.D., \& Pettis, J.S. (2012). Differential expression of immune genes of adult honey bee (Apis mellifera) after inoculated by Nosema ceranae. Journal of Insect Physiology, 58, 1090-1095. D0l: 10.1016/j.jinsphys.2012.04.016

Chauzat, M.-P., Higes, M., Martin-Hernandez, R., Meana, A., Cougoule, N., Faucon, J.P. (2007). Presence of Nosema ceranae in French honey bee colonies. Apidologie, 46, 127-128. DOl: 10.3896/ IBRA.1.46.2.12

Chauzat, M.-P., Laurent, M., Riviere, M.-P., Saugeon, C., Hendrikx, P., Ribiere-Charbert, M. (2014). A panEuropean epidemiological study on honeybee colony losses 2012-2013 - EPILOBEE - 2012-2013. Retrieved October 22, 2014 from, https://ec.europa. eu/food/sites/food/files/animals/live_animals/bees/ docs/bee-report_en.pdf

Chauzat, M.-P., Martel, A.-C., Zeggane, S., Drajnudel, P., Schurr, F., Clément, M.-C., Ribière-Chabert, M., Aubert, M., Faucon, J.-P. (2010). A case control study and a survey on mortalities of honey bee colonies (Apis mellifera) in France during the winter of 20056. Journal of Apicultural Research, 49, 40-51. DOl: 10.3896/IBRA.1.49.1.06

Chen, Y., Evans, J.D., Smith, I.B., \& Pettis, J.S. (2008). Nosema ceranae is a long-present and widespread microsporidean infection of the European honey bee (Apis mellifera) in the United States. Journal of Invertebrate Pathology, 97, 186-188. DOl: 10.1016/j. jip.2007.07.010

Copley, T.R. \& Jabaji, S.H. (2011). Honeybee glands as possible infection reservoirs of Nosema ceranae and Nosema apis in naturally infected forager bees. Journal of Applied Microbiology, 712, 15-24. DOl: 10.1111/j.1365-2672.2011.05192.x 


\section{J. APIC. SOLI. YOL. 60 NO. 2.2016}

Cox-Foster, D.L., Conlan, S., Holmes, E.C., Palacios, G., Evans, J.D., Мoran, N.A., ... Lipkin, W.I. (2007). A metagenomic survey of microbes in honey bee colony collapse disorder. Science, 318, 283-287. D0l: 10.1126/science.1146498

Dainat, B., Evans, J.D., Chen, Y.P., Gauthier, L., Neumann, P. (2012). Predictive markers of honey bee colony collapse. PLoS One, 7, e32151. DOl: 10.1371/ journal.pone.0032151

Derakhshifar, l., Köglberger, H., Oberlerchner, J., Moosbeckhofer, R. (2009). Incidence of Nosema spp. and colony performance in Austria 2006-2008. In Nosema disease: lack of knowledge and work standardization (COST Action FA0803). Guadalajara - Spain. Retrieved lanuary 25, 2012 from, http://www.coloss. org/news/nosema-workshop-proceedings-online

Dussaubat, C., Maisonnasse, A., Alaux, C. Tchamitchan, S., Brunet, J.L., Plettner, E., Belzunces, L.P., Le Conte, Y. (2010). Nosema spp. infection alters pheromone production in honey bees (Apis mellifera). Journal of Chemical Ecology, 36, 522-525. DOl: 10.1007/ s10886-010-9786-2

Ellis, J.D. \& Munn, P.A. (2005). The worldwide health status of honey bees. Bee World, 86, 88-101. DOl: 10.1080/0005772X.2005.11417323

Fries, I. (2010). Nosema ceranae in European honey bees (Apis mellifera). Journal of Invertebrate Pathology, 103, S73-79. DOl: 10.1016/j.jip.2009.06.017

Fries, l., Ekbohm, G., \& Villumstad, E. (1984). Nosema apis, sampling techniques and honey yield. Journal of Apicultural Research, 23, 102-105.

Fries, I., Feng, F., da Silva, A., Slemenda, S.B., Pieniazek, N.J. (1996). Nosema ceranaen. Sp. (Microspora, Nosematidae), morphological and molecular characterization of a microsporidian parasite of the Asian honey bee Apis cerana (Hymenoptera, Apidae). European Journal of Protistology, 32, 356-365. D0l: 10.1016/ S0932-4739(96)80059-9

Gajda, A. \& Topolska, G. (2009). Most probable causes of colony losses during the winter of 2008/2009 in Poland. In Proceedings of 5 th COLOSS conference (p. 41). Montpellier - France.

Genersch, E., von der Ohe, W., Kaatz, H., Schroeder, A., Otten, C., Büchler, R., ... Rosenkranz, P. (2010). The German bee monitoring project: a long term study to understand periodically high winter losses of honey bee colonies. Apidologie, 41, 332-352. DOl: 10.1051/ apido/2010014

Gisder, S., Hedtke, K., Möckel, N., Frielitz, M.-C., Linde, A., Genersch, E. (2010). Five-year cohort study of Nosema spp. in Germany: does climate shape virulence and assertiveness of Nosema ceranae? Applied and Environmental Microbiology, 76, 30323038. DOl: 10.1128/AEM.03097-09

Higes, M., Martín, R., \& Meana, A. (2006). Nosema ceranae, a new microsporidian parasite in honeybees in Europe. Journal of Invertebrate Pathology, 92,93-95. DOl: 10.1016/j.jip.2006.02.005

Higes, M., Garcia-Palencia, P., Martin-Hernandez, R., \& Meana, A. (2007). Experimental infection of Apis mellifera honeybees with Nosema ceranae (Microsporidia). Journal of Invertebrate Pathology, 94, 211217. DOl: 10.1016/j.jip.2006.11.001

Higes, M., Martin-Hernandez, R., Botias, C., Bailon, E.G., Gonzalez-Porto, A.V., Barrios, L., ... Meana, A (2008). How natural infection by Nosema ceranae causes honeybee colony collapse. Environmental Microbiology, 10, 2659-2669. DOI: 10.1111/j.14622920.2008.01687.x

Higes, M., Martín-Hernández, R., Garrido-Bailón, E. González-Porto, A.V., García-Palencia, P., Meana, A., ... Bernal, J.L. (2009). Honey bee colony collapse due to Nosema ceranae in professional apiaries. Environmental Microbiology Reports, 1, 110-113. Dol: 10.1111/j.1758-2229.2009.00014.x

Invernizzi, C., Abud, C., Tomasco, I.H., Harriet, I., Ramallo, G., Campá, J., ... Mendoza, Y. (2009). Presence of Nosema ceranae in honeybees (Apis mellifera) in Uruguay. Journal of Invertebrate Pathology, 101, 150-153. DOl: 10.1016/j.jip.2009.03.006 


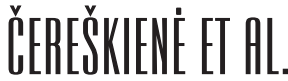

Klee, I., Besana, A.M., Genersch, E., Gisder, S., Nanetti, A., Tam, D.Q... ... \& Paxton, R.J. (2007). Widespread dispersal of the microsporidian Nosema ceranae, an emergent pathogen of the western honey bee, Apis mellifera. Journal of Invertebrate Pathology, 96, 1-10. DOl: 10.1016/j.jip.2007.02.014

Korpela, S. (2009). Nosema situation in Finland. In Proceedings of 5th COLOSS conference (p. 48). Montpellier - France.

Mariani, F., Maggi, M., Porrini, M., Fuselli, S., Caraballo, G., Brasesco, C., Barrios, C., Principal, J., Martin, E. (2012). Parasitic interactions between Nosema spp. and Varroa destructor in Apis mellifera colonies. Zootecnia Tropical, 3a1), 81-90.

Martín-Hernández, R., Meana, A., Prieto, L., Salvador, A.M., Garrido-Bailon, E., \& Higes, M. (2007). Outcome of colonization of Apis mellifera by Nosema ceranae. Applied and Environmental Microbiology, 73, 63316338. DOI: 10.1128/AEM.00270-07

Mayack, C. \& Naug, D. (2009). Energetic stress in the honeybee Apis mellifera from Nosema ceranae infection. Journal of Invertebrate Pathology, 100, 185-188. DOl: 10.1016/j.jip.2008.12.001

Michalczyk, M., Sokół, R., \& Szczerba-Turek, A. (2013). Phylogenetic analysis of Nosema apis and Nosema ceranae small subunit 16S rRNA in honey bees (Apis mellifera) from north-eastern Poland. Medycyna Weterynaryjna, 69. 733-735.

Michalczyk, M., Sokół, R., Szczerba-Turek, A., BancerzKisiel, A. (2011). A comparison of the effectiveness of the microscopic method and the multiplex PCR method in identifying and discriminating the species of Nosema spp. spores in worker bees (Apis mellifera) from winter hive debris. Polish Journal of Veterinary Sciences, 14, 385-391. D0l: 10.2478/v10181011-0058-z

OIE(2008) Nosemosis of honey bees. OIE Terrestrial Manual.

Paxton, R.J. (2010). Does infection by Nosema ceranae cause Colony Collapse Disorder in honey bees

\section{Nosema infection in Lithuania}

(Apis mellifera)? Journal of Apicultural Research, 49(1), 80-84. DOI: 10.3896/IBRA.1.49.1.11

Paxton, R.J., Klee, J., Korpela, S., Fries, I. (2007). Nosema ceranae has infected Apis mellifera in Europe since at least 1998 and may be more virulent than Nosema apis. Apidologie, 38, 558-565. DOI: 10.1051/ apido:2007037

Pickard, R.S. \& El-Shemy, A.A.M. (1989). Seasonal variation in the infection of honeybee colonies with Nosema apis Zander. Journal of Apicultural Research, 28,93-100.

Ratnieks, F.L.W. \& Carreck, N.L. (2010). Clarity on honey bee collapse? Science, 327,152-153. DOl: 10.1126/ science.1185563

Stevanovic, J., Stanimirovic, Z., Genersch, E., Kovacevic, S. R., Ljubenkovic, J., Radakovic, M., Aleksic, N. (2011). Dominance of Nosema ceranae in honey bees in the Balkan countries in the absence of symptoms of colony collapse disorder. Apidologie, 42, 49-58. DOl: 10.1051/apido/2010034

Stevanovic, J., Simeunovic, P., Gajic, B., Lakic, N., Radovic, D., Fries, I., Stanimirovic, Z. (2013). Characteristics of Nosema ceranae infection in Serbian honey bee colonies. Apidologie, 44, 522-536. DOl: 10.1007/ s13592-013-0203-2

Tapaszti, Z, Forgách, P., Kövágó, C., Békési, L., Bakonyi, T., \& Rusvai, M. (2009). First detection and dominance of Nosema ceranae in Hungarian honeybee colonies. Acta Veterinaria Hungarica, 57, 383-388. DOl: 10.1556/AVet.57.2009.3.4

Tlak Gajger, I., Vugrek, O., Grilec, D., Petrinec, Z. (2010). Prevalence and distribution of Nosema ceranae in Croatian honeybee colonies. Veterinární medicína, 55:457-462.

Topolska, G., Gajda, A., \& Hartwig, A. (2008). Polish honey bee colony-loss during the winter of 2007/2008. Journal of Apicultural Science, 52, 95103.

Traver, B.E., Williams, M.R., \& Fell, R.D. (2012). Comparison of within hive sampling and seasonal activity of 
Nosema ceranae in honey bee colonies. Journal of Invertebrate Pathology, 109, 187-193. DOl: 10.1016/j. jip.2011.11.001

Van Engelsdorp, D., Evans, J.D., Saegerman, C., Mullin, C., Haubruge, E., Nguyen, B.K., ... Pettis, I.S. (2009). Colony collapse disorder: a descriptive study. PLoS One, 4, e6481. D0l: 10.1371/journal.pone.0006481

Vejsnæs, F., Nielsen, S.L., \& Kryger, P. (2010). Factors involved in the recent increase in colony losses in Denmark. Journal of Apicultural Research, 49, 109110. DOl: 10.3896/IBRA.1.49.1.20

Whitaker, J., Szalanski, A.L., \& Kence, M. (2011). Molecular detection of Nosema ceranae and $N$. apis from Turkish honey bees. Apidologie, 42, 174-180. DOl: 10.1051/apido/2010045

Zander, E. (1909). Tierische Parasiten als Krankenheitserreger bei der Biene. Münchener Bienenzeitung, 37: 196-204. 
